\title{
Do Environmental Practices of Enterprises Constitute an Authentic Green Marketing Strategy? A Case Study from Mexico
}

\author{
Andrea Trujillo $^{1}$, Pilar Arroyo ${ }^{2} \&$ Lorena Carrete $^{3}$ \\ ${ }^{1}$ School of Business, Tecnológico de Monterrey, Campus Santa Fe, Mexico \\ ${ }^{2}$ Industrial Engineering Department, Tecnológico de Monterrey, Campus Toluca, Mexico \\ ${ }^{3}$ Management Sciences and Marketing Department, Tecnológico de Monterrey, Campus Toluca, Mexico \\ Correspondence: Andrea Trujillo, School of Business, Tecnológico de Monterrey, Campus SantaFe, Mexico. Ave. \\ Carlos Lazo \#100, 01389, Santa Fe, Delegación Álvaro Obregón, Distrito Federal, Mexico. Tel: 52-55-9177-8000 \\ ext. 7765. E-mail: andrea.trujillo@itesm.mx
}

Received: November 4, 2013

Accepted: December 21, 2013 Online Published: January 20, 2014

doi:10.5539/ijbm.v9n2p175

URL: http://dx.doi.org/10.5539/ijbm.v9n2p175

\begin{abstract}
Private enterprises have responded to the increasing concern about environmental deterioration by implementing green actions with different grades of efficacy in terms of environmental and business performance. The aim of this work was to outline how firms that operate in a context with weak social and governmental pressures like Mexico are considering environmental issues into their strategies. By using a qualitative research approach, this study collected information of multiple cases comprising multinationals, Mexican firms with international operations and Mexican firms with local operations. Information was analyzed to get a deep understanding about how 4Ps of product, price, place (distribution) and promotion (communication) of the traditional marketing mix are addressed via green practices. The two dominant greening strategies identified, "resource savings and waste reduction" and "certification and acknowledgment of environmental responsibility", reflect a short-term perspective driven by immediate economic and legitimacy benefits. A well structured green marketing strategy was not identified even for large multinationals.
\end{abstract}

Keywords: green strategies, marketing mix, environmental responsibility, Mexico, multiple case studies

\section{Introduction}

The degradation of the environment has been a major topic of research in multiple disciplines. The interest in environmental issues in management journals increased notably during the 1989-1998 decade (Leonidou \& Leonidou, 2011) and new research questions have been continuously addressed since then. Environmental management research has significantly transformed, going from exploratory studies and multi-disciplinary research including a multi-cultural perspective to more sophisticated research designs with a quantitative and conclusive orientation. The idea that satisfaction of human needs and economic growth justifies ecological detriment has been replaced by the concept of sustainability development.

From the marketing perspective, concepts like social marketing (Kotler \& Levy, 1969), responsible consumption and green marketing have contributed to increase the sensitivity toward environmental problems. In the 1970s, firms used marketing to communicate compliance with environment regulations. In the 1980s, the main issue was how to reduce environmental costs. Then in the 1990s, the interest turned to the development of the green market. These reactive environmental measures changed by 2000 to a more proactive strategy oriented to the creation of an environmental culture and the achievement of competitive advantage from being "green". This historical evolution influenced marketing management, which advanced from a socially responsible perspective to the implementation of an authentic green marketing strategy able to contribute to sustainable development.

The research on environmental marketing/management includes many topics. The main thematic areas are (Leonidou \& Leonidou, 2011): marketing management aspects, environmental management, environmental corporate strategy, regulatory environment, environmental strategy implications, corporate environmental response and environmental advertising. Marketing management arose as the main category $(40.4 \%$ of the total articles reviewed) covering these main topics: how the marketing mix (product development, communication, 
branding, pricing and eco-labeling) supports the enterprise's financial and environmental objectives, the psyecology of individuals, segmentation of consumers and identification of green marketing niches, the acquisition of environmental capabilities, the formation of green alliances, green supply chains and the evaluation of environmental strategies (Menguc \& Ozanne, 2005).

All these research topics are not only relevant to academia but also to organizations because they represent a potential opportunity to attain: 1) cost reduction through energy savings, substitution and diminution in the use of materials, and the introduction of more efficient technologies; 2) increased revenues resulting from developing the green market that is particularly profitable and in expansion in developed countries (Lyon \& Maxwell, 1999); and 3) competitive advantage through a differentiated green strategy.

Most of the recent research (1999-2008) on environmental management and marketing has been focused on Europe (29\%), the more advanced region in terms of sustainable practices, and on North America, especially the USA (22.6\%). In most of the articles revised by Leonidou \& Leonidou (2011), the unit of analysis was the firm, with emphasis on larger businesses, followed by the study of consumers' attitudes, motivations and behaviors. The research coverage has been mainly domestic (28.7\%) but with an increasing interest in the international market. Even though the research on environmental management has contributed to create a meaningful body of knowledge, additional research in the following topics is still required: 1) benchmark and case studies that suggest guidelines for the elaboration of an effective green marketing strategy; 2) study of the performance outcomes of different green strategies; 3) development of innovative green products following an enviropreneurialism perspective that combine ecological attributes with customer needs; 4) evaluation of the impact of closed-loop supply chains on the environment and on the firm's competitive position; 5) deep understanding of the private firms' motivations to embrace green strategies; and 6) studies involving firms with different profiles and the replication of studies in different socioeconomic and environmental contexts (Cronin, Smith, Gleim, Ramírez \& Martínez, 2011, Leonidou \& Leonidou, 2011).

The aim of this work was to cover to some extent the topics 1 and 6 for the particular case of firms operating in Mexico. The study also looks to provide empirical evidence that the limited scope of current green marketing actions justifies the criticism to the green marketing concept and requires additional efforts to prevent the sending of misleading signals to the market (Barkin, 2004, Melton \& Tinsley, 1999, Peattie \& Crane, 2005). Since current information about the environmental strategies followed by firms located in the country is scarce and dispersed, a qualitative approach was adopted to systematically examine how environmental actions are incorporated into the marketing concept by firms with different sizes, different origins of capital (national and foreign) and operating in different sectors. The objectives of the study were the following:

- To identify how advanced are the green actions currently implemented by firms operating in Mexico?

- To assess if current environmental practices integrate a well structured green marketing strategy?

This study provides in-depth information about how firms deal with environmental issues when the social pressure and regulations of their business context are weak and still developing.

This remainder of this paper is structured in four sections. The first section introduces the concepts of green strategy and green marketing. The second section describes the methodology used to collect and analyze qualitative in-depth information from multiple firms with different profiles (size, market coverage and origin of capital). The third section presents results and discusses main findings. The last section provides conclusions and managerial implications, states limitations of the study and outlines future research.

\section{Theoretical Background}

Economics and traditional theories of the firm state the goal of the organization is to create economic value for equity holders. But from a social perspective, firms need to voluntarily adopt a triple-need bottom line of evaluation, which includes economic, social and environmental objectives that respond to the requirements of multiple stakeholders (Commission of European Communities [CEC], 2001, Milliman, Ferguson \& Sylvester, 2008). The theory of stakeholders has been used to explain why firms implement Corporate Social Responsibility (CSR) policies (Jamali, 2008) and design green strategies (Cronin et al. 2011, Defee, Esper \& Mollenkopt, 2009). The core of this theory is that firms respond to multiple stakeholders-consumers, government, investors, supply chain partners, NGOs, employees and society in general- whose expectations, values, preferences and actions influence the organization's strategies because not all of them think exclusively in financial terms. As a consequence, organizations need to consider multiple options to create value and improve their performance to address the demands of all groups who are affected by their business decisions. Then stakeholders are perceived as a regulative structure that prescribes or restrains organizational decisions 
(Moir, 2011).

Porter and Kramer (2006) contend that firms implement CSR and environmental programs in a reactive manner and based on doing something good. As a result of this limited perspective, many of the social and environmental strategies have low impact on the firm, the environment and the society. To the extent that firms adopt a more proactive attitude and modify their current evaluation system to include along with financial objectives, environmental and social ones, more effective green strategies will be developed. Such strategies require incorporating ecological objectives in each of the organization's functional areas including marketing.

\subsection{Green Strategies}

Cronin et al. (2011) performed an integrative review of environmental management and marketing articles to investigate, among other issues, the link between green strategies and a firm's performance. It is argued that unless higher profits are expected, it is unlikely firms will adopt green strategies. However, the benefits that a firm may get from green initiatives are unclear and contradictory because of the complexity of the relation between environmental management strategies and firm performance. It seems the direct benefits are not better revenues but decreased liability, higher levels of employee commitment, increased consumer satisfaction and greater firm value in terms of stock appreciation (or depreciation) depending on positive (or negative) social and environmental actions.

Several environmental strategies may be set up by firms, Cronin et al. (2011) identified the following: 1) green innovation, 2) greening the organization and 3) green alliances. The first strategy refers to the creation of innovative products that strive to protect or enhance the natural environment by conserving energy and/or resources and reducing or eliminating use of toxic agents, pollution and waste (Ottman, Stafford \& Hartman, 2006). The design of green products may be based on: 1) source reduction that tries to eliminate pollution in the source itself via weight reduction (e.g. in package volume), material substitution and product life extension; and 2) waste management that focuses on design for easy disassembly, recyclability and final disposal (Bhat, 1993). The firms that use this first global strategy generate product and technology innovations by integrating environmental sustainability into product development and operations. The benefits of this environmentally-friendly strategy are increased efficiency in the use of resources, product differentiation, participation in new markets, improved corporate image and market position (Dangelico \& Pujari, 2010). It is important to note that the consumer's concern about environmental problems does not necessarily translate into purchase of green products, as demonstrated by the low market share of ecological products (less than 4\% according to Cronin et al., 2011). So the advantages of this global strategy as a marketing strategy are relatively new and require additional exploration (Baumann, Boons \& Bragd, 2002).

Greening the organizations is another strategy mainly driven by cost reduction and efficiency in the firm's operations. Firms that pursue this strategy are more focused on environmental aspects within their internal processes. Greening strategies include:

a) Waste reduction or reduction of operation byproducts through a lean system approach that improves the organizational processes, as opposed to treating or disposing of the waste produced.

b) System certification through the adoption of formalized environmental management systems and the fulfillment of certified environmental norms (for example ISO 140001) that demonstrate the social and environmental responsibility of the organization. Certifications contribute to the improvement of the firm's image but their role in consumers' perceptions and environmental performance improvement beyond compliance with current regulations is unclear (Miles \& Russell, 1997; Yin \& Ma, 2009).

c) Supply chain (SC) management that considers the influence and contribution of business partners, especially buyers committed with green sourcing, to integrate environmental strategies across all SC activities to green the chain (Yin \& Ma, 2009). The greening of the supply chain involves the integration of environmental concerns in the management of the chain, from the selection and supply of materials through the manufacturing and distribution of products as well as the management of products at the end of their life cycle (Srivastava, 2007).

The final strategy, the formation of green alliances, represents an opportunity to enhance the firm's green capabilities via networking; the selection of partners with valuable environmental management capabilities is critical. This last strategy seems to be the less explored one but past studies have recognized alliances as a critical factor which can influence small and medium firms to embrace environmental practices (Zhou, 2009). The alliances between private firms and governmental agencies is an opportunity to take advantage of the expertise of environmental professionals (attorneys, economists and researchers) to expand the green actions of 
private firms and gain long term advantage or legitimacy (Hemphill, 1995).

\subsection{Green Marketing Strategies}

Environmental or "green" marketing is an emerging marketing venue by which organizations address environmental issues to contribute to sustainable development (Fraj, Martínez \& Matute, 2008). Even within the general classification of corporate environmental strategies, it is difficult to identify typologies based solely on a green marketing perspective. Nevertheless, typologies based on the green marketing concept have been classified as tactical or passive, quasi-strategic or operative, and strategic (Rivera-Camino, 2007). These strategies are implemented by combining the different elements of the 4Ps marketing mix -product, price, communication (promotion) and distribution (place)-and have a clear customer orientation that distinguishes them from greening strategies.

The management of the communication component of the firms' strategies has been hardly criticized in literature. For example, Peattie and Crane (2005) when citing King (1985) argued that the promotion of traditional products as ecological ones with the expectation of increasing sales, results in a lack of credibility on the part of consumers regarding the true intentions of the development and promotion of green products. Even those firms that have authentic green products have followed a partial communication strategy by focusing solely on the product's green attributes instead of promoting all its benefits (Ottman, et al., 2006). This perspective fails to recognize that consumer buy products in the first place to satisfy needs, and since green products represent a higher cost/benefit ratio for the consumers (inconvenience and higher price vs. unclear environmental benefits), they do not feel particularly attracted by this kind of green advertising (Roper ASW, 2003). Communication must go beyond green product advertising and include among its objectives the environmental education of the consumer (what to buy, how to dispose of final products) and the diffusion of the green activities realized by the firm (reduction of water and energy, recycling, reforestation) (Esty \& Winston, 2009).

Green products go from the design of new products (less harmful to the environment than current ones) to the redesign of original products to mitigate their impact on the environment (Yi \& Tsai, 2007). The design of green products involves the minimization of the impact on the environment of both the product and its manufacturing process (Fiskel, 2001 cited by Yi-Chan \& Tsai). There are different ways to evaluate a green design; one is based on the analysis of the product life cycle (Bhat, 1993). Products have a different impact on the environment depending on the stage of their life cycles because the consumption of resources and the amount of waste produced varies at each stage (Yi-Chan \& Tsai, 2007). The development of ecological products as a component of the marketing mix must result in innovations that make a good match between the product characteristics and the consumer needs (Rao \& Reddy, 2012, Yi-Chan \& Tsai, 2007). This situation calls for additional efforts in the design and positioning of this type of products in the consumer market. Enviropreneurial marketing recognizes green products represent an opportunity to exploit new markets if the innovation satisfies the economic and environmental objectives of consumers.

In relation to distribution, this is the marketing-mix component with the greatest potential to reduce environmental impacts according to some authors (Fraj, Martínez \& Matute, 2011). The research on green distribution has focused on the advantages of: 1) design of a transportation network (modes and routes) to minimize distances, reduce pollutant emissions and decrease fuel use (Rondinelli \& Berry, 2000), and 2) design of the supply chain to integrate the direct and indirect logistics activities to ensure an efficient flow of materials and information (Defee, et al., 2009; Gobbi, 2011). This requires determining the best location of facilities, (direct and reverse) distribution centers and final point of sales (recuperation sites) such that the environmental impact of the logistics activities is minimized. From a marketing perspective, one consideration to keep in mind is that green distribution systems may require additional efforts such as the redesign of the distribution network and the development of secondary markets where refurbished products or recycled components may be commercialized (Guide \& Van Wassenhove, 2009).

Price is the least studied component in the green marketing literature. The research about price has been oriented to explore the willingness of consumers to pay an extra price for "green" products (Fotopoulos \& Krystallis, 2002) and the perception of the economic risk involved when refurbished products or products manufactured from recycled components are acquired. To set prices for ecological products, firms should consider that consumers are looking forvalue and convenience (McDaniel \& Rylander, 1993), with this situation being more evident in the case of consumers from lower classes. This segment cannot afford to buy environmentally friendly products if they are significantly more expensive than their conventional counterparts (Author, 2012; Chan, 1999; Chan \& Lau, 2000; Manaktola \& Jauhari, 2007). Then the pricing strategy of green products must 
take into account the balance between the environmental benefits and the cost of acquiring a new product that already has substitutes in the market with perhaps lower prices (Fraj, et al., 2011). Only those consumers whose values are in alignment with the ecological product will be willing to pay a premium price.

In summary, the design of a green marketing strategy poses the challenge of managing ecological practices across the four 4Ps. A green marketing strategy based only on the promotion of the environmental attributes of a product will not contribute significantly to the concept of sustainability (Chen \& Lin, 2011; Peattie \& Crane 2005). The limited scope of some of the green actions deployed by firms, for example communication (promotion), may result in a lack of credibility about the true intentions of organizations to be green (King, 1985). The advantage of implementing an authentic green marketing strategy is to gain competitiveness either by reduction of environmental costs, the differentiation of the firm's products as ecological or improved market reputation (Fraj et al., 2008).

\section{Methodology}

We used a qualitative approach to get a deeper insight on how firms in Mexico respond to the increasing environmental concerns and consider sustainability challenges in their marketing strategy. An inductive multiple case study methodology was employed. Yin (2003) defined case study research as an empirical inquiry that investigates a contemporary phenomenon within its real-life context and in which multiple sources of evidence (interviews and secondary open data) are used. The case study method is desirable when "how" or "why" questions are posed about a complex issue or object over which the researcher has no control. When investigating events that may have little theoretical background or where there is no systematic information about the phenomenon under study, the researcher might select cases to generate preliminary theoretical propositions.

A series of in-depth interviews with executives and managers in thirty four companies was conducted. The choice of companies was based mainly on their commitment to the environment; only those firms with a current program as evidenced from their Web pages or open documents were considered. Multinationals and Mexican firms with local and foreign operations were selected to obtain a more representative pool of firms. The final selection of companies was made after checking that there were firms from different sizes and sectors (commercial, manufacturing and service).

Table 1. Profile of the companies studied

\begin{tabular}{|c|c|c|c|}
\hline Company, origin of capital & Sector of activity & $\begin{array}{l}\text { Size (number of } \\
\text { employees) }\end{array}$ & Role of interviewee \\
\hline $\begin{array}{l}\text { A1 } \\
\text { Mexican local }\end{array}$ & $\begin{array}{l}\text { Service, recycling of electronic } \\
\text { waste }\end{array}$ & Small & Owner \\
\hline $\begin{array}{l}\text { A2 } \\
\text { Mexican local }\end{array}$ & Service, restaurant franchise & Large & $\begin{array}{l}\text { Customer service and sales } \\
\text { manager }\end{array}$ \\
\hline $\begin{array}{l}\text { A3 } \\
\text { Mexican local }\end{array}$ & $\begin{array}{l}\text { Service, solar thermal and } \\
\text { electricity provider }\end{array}$ & Small & $\begin{array}{l}\text { Customer service and sales } \\
\text { manager }\end{array}$ \\
\hline $\begin{array}{l}\text { A4 } \\
\text { Mexican local }\end{array}$ & Service, restaurant & Small & Owner \\
\hline $\begin{array}{l}\text { A5 } \\
\text { Mexican local }\end{array}$ & Commerce, pet products & Large & Sales manager \\
\hline $\begin{array}{l}\text { A6 } \\
\text { Mexican local }\end{array}$ & Service, technical services & Small & Sales manager \\
\hline $\begin{array}{l}\text { A7 } \\
\text { Mexican local }\end{array}$ & Commerce, garden products & Small & Project manager \\
\hline $\begin{array}{l}\text { A8 } \\
\text { Mexican local }\end{array}$ & $\begin{array}{l}\text { Industry, manufacturer of green } \\
\text { products }\end{array}$ & Small & Sales manager \\
\hline $\begin{array}{l}\text { A9 } \\
\text { Mexican local }\end{array}$ & $\begin{array}{l}\text { Service, expo and conference } \\
\text { coordinator }\end{array}$ & Small & Director \\
\hline $\begin{array}{l}\text { A10 } \\
\text { Mexican local }\end{array}$ & $\begin{array}{l}\text { Industry, } \\
\text { manufacturer of disposable } \\
\text { containers }\end{array}$ & Small & Operations and logistics manager \\
\hline $\begin{array}{l}\text { A11 } \\
\text { Mexican local }\end{array}$ & Service, communication & Large & Communication manager \\
\hline
\end{tabular}




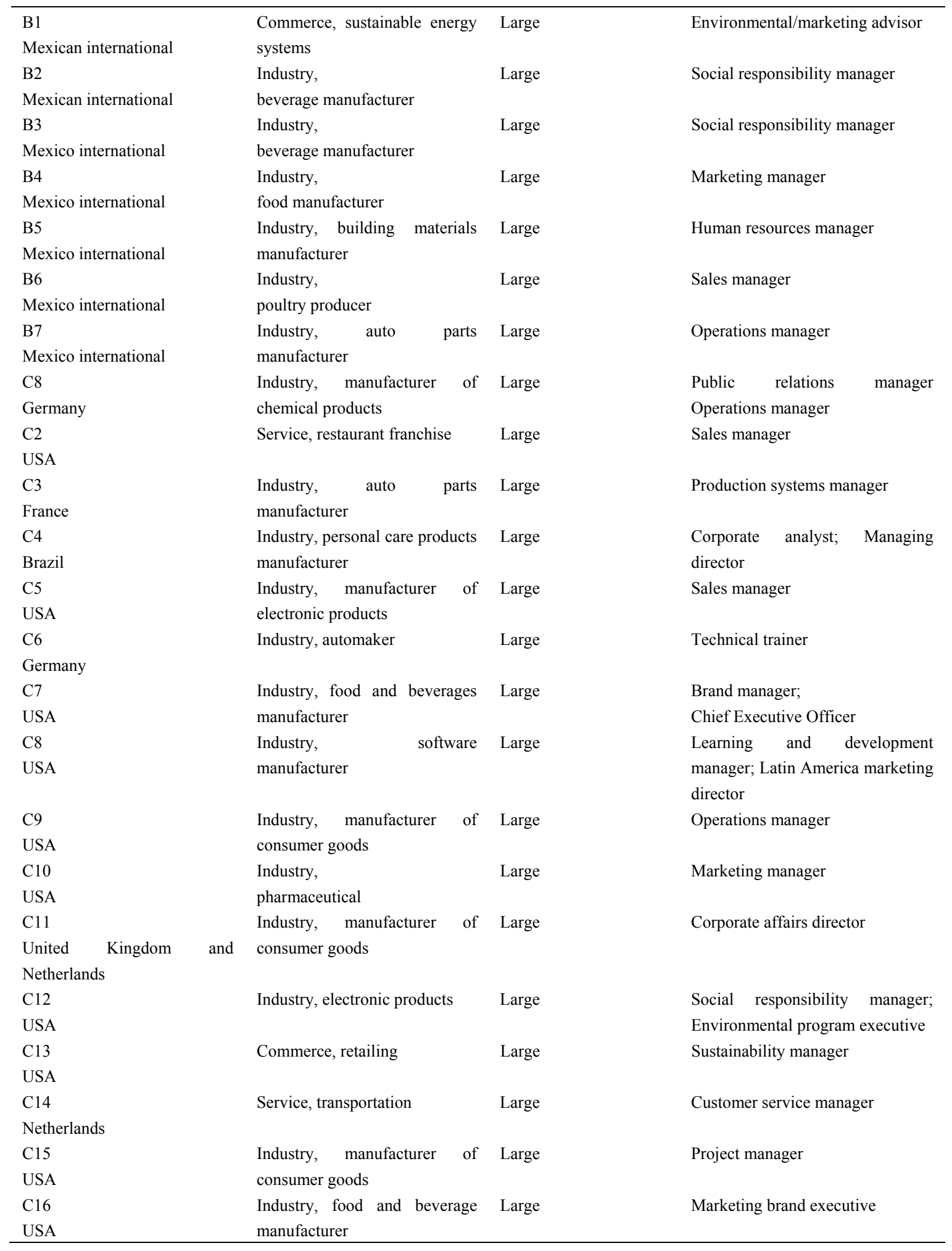

A general description of the companies in the study is given in Table 1. The size of the company is established in terms of Mexican standards based on the number of employees. Twenty two of the companies are in the consumer market, five in the industrial market and the remaining seven serve both the $\mathrm{B} 2 \mathrm{~B}$ and $\mathrm{B} 2 \mathrm{C}$ markets. Companies are identified by codes $(\mathrm{A}=$ Mexican local, $\mathrm{B}=$ Mexican international and $\mathrm{C}=$ multinationals with operations in Mexico) to assure anonymity as requested by the interviewees.

The interviews were semi-structured and focused on the following question: "What is the extent of the current 
environmental programs of the firm and the green marketing mix that supports these programs?" The interviews were conducted during personal visits to companies, and clarifications were sought through e-mails and phone calls. The average length of an interview was limited to an hour because Mexican executives are very reluctant to have long interviews. Information gathered during the interviews was transcribed for analysis.

The method used to analyze the information was Thematic Analysis (Boyatzis, 1998). The analysis consisted only of two phases: the development of themes and codes, and the validation of codes. The first phase was performed independently by the authors and then cross-validated until a consensus was reached. Generally, the reliability of qualitative research is assured when the codes developed by different researchers are in total agreement or, in cases of discrepancies, original data are revised to attain consensus. To strengthen and verify the quality of the interview data, other sources of information about the environmental activities of the companies were also analyzed, such as companies Web sites and published documents open to the general public. In some cases (eight), two different executives were interviewed to cross-check information and increase the validity of results. General emerging themes shared by all interviews are discussed in the following section.

\section{Findings and Discussion}

\subsection{Current General Green Strategies}

The first part of the analysis was the identification and classification of all activities in support of the environment performed by the enterprises interviewed. Separate tables (shown below as Tables 2, 3 and 4) for each type of company (Mexican local Mexican with foreign operations, and multinational) were prepared because of the interest to compare the activities deployed by companies with different capital origins.

Table 2. Description of green activities performed by Mexican companies with local operations

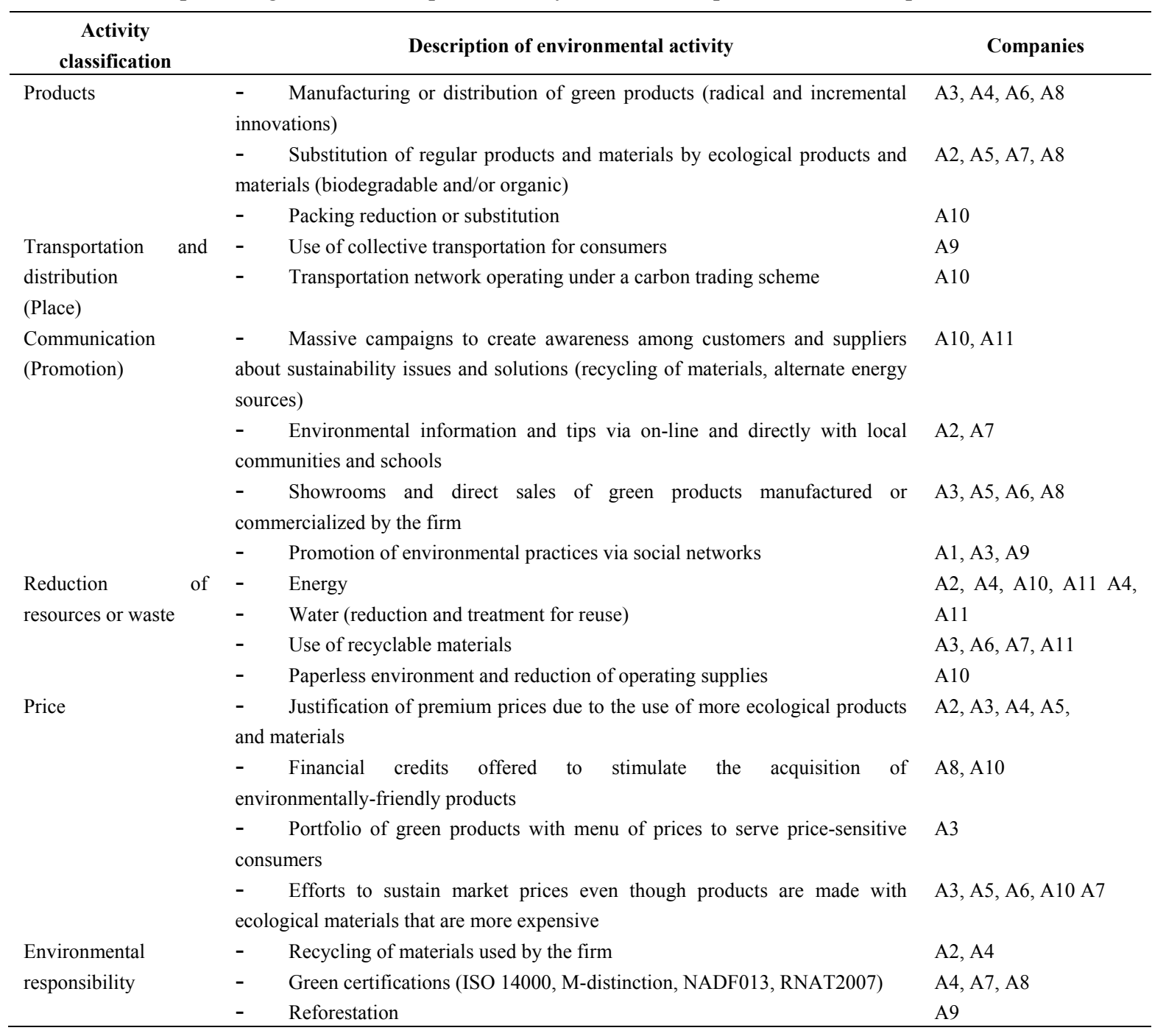


Table 3. Description of green activities performed by Mexican companies with foreign operations

\begin{tabular}{|c|c|c|}
\hline Activity classification & Description of environmental activity & Companies \\
\hline Products & $\begin{array}{l}\text { - } \\
\text { and incremental innovations) } \\
\text { - } \quad \text { Substitution/reduction of materials } \\
\text { - } \quad \text { Packing reduction, substitution of packing materials and } \\
\text { use of recyclable packages and bottles }\end{array}$ & $\begin{array}{l}\text { B1, B5 } \\
\text { B4 } \\
\text { B2, B3 }\end{array}$ \\
\hline Processes & $\begin{array}{l}\text { - Redesign of production processes to save water or reduce } \\
\text { pollution } \\
\text { - Byproducts and waste are processed or sold to } \\
\text { manufacture additional products }\end{array}$ & $\begin{array}{l}\text { B5, B6 } \\
\text { B3, B6 }\end{array}$ \\
\hline $\begin{array}{l}\text { Reduction of resources and waste } \\
\text { in general operations }\end{array}$ & $\begin{array}{ll}- & \text { Energy } \\
- & \text { Use of alternative sources of energy } \\
- & \text { Water (treatment for reuse) } \\
- & \text { Use of recyclable materials } \\
- & \text { Paperless environment and reduction of operating } \\
\text { supplies }\end{array}$ & $\begin{array}{l}\text { B2, B3, B4, B5 B4, B2, B3, } \\
\text { B6 } \\
\text { B5 } \\
\text { B5 } \\
\text { B5 }\end{array}$ \\
\hline $\begin{array}{l}\text { Communication } \\
\text { (Promotion) }\end{array}$ & $\begin{array}{l}\text { - Massive campaigns to create awareness among } \\
\text { customers and suppliers about sustainability issues and } \\
\text { solutions (recycling of materials, alternate energy sources) } \\
\text { - Environmental information and tips via online and } \\
\text { directly with local communities and schools } \\
\text { - Showrooms and direct sales of green products } \\
\text { manufactured or commercialized by the firm } \\
\text { - Promotion of environmental practices via social } \\
\text { networks }\end{array}$ & B1, B2, B3, B5 \\
\hline Prices & $\begin{array}{l}\text { - } \quad \text { Efforts to sustain market prices even though products are } \\
\text { made with ecological materials that are more expensive } \\
\text { - Justification of premium prices due to the use of more } \\
\text { ecological products and materials } \\
\text { - Financial credits offered to stimulate the acquisition of } \\
\text { environmentally-friendly products }\end{array}$ & $\begin{array}{l}\text { B1 } \\
\text { B1 }\end{array}$ \\
\hline Environmental responsibility & $\begin{array}{l}\text { - } \quad \text { Recycling and reuse of materials used by the firm } \\
\text { - } \quad \text { Green certifications (ISO 14000) and carbon footprint for } \\
\text { products } \\
\text { - } \quad \text { Reforestation } \\
\text { - } \quad \text { Preservation of regional water sources }\end{array}$ & $\begin{array}{l}\text { B2, B3, B7 } \\
\text { B2, B5, B7 }\end{array}$ \\
\hline
\end{tabular}

Table 4. Description of green activities performed by multinationals with operations in Mexico

\begin{tabular}{|c|c|c|}
\hline Activity classification & Description of environmental activity & Companies \\
\hline \multirow[t]{3}{*}{ Products } & $\begin{array}{l}\text { - Research and development, and manufacturing of green } \\
\text { products (radical and incremental innovations) }\end{array}$ & $\begin{array}{l}\mathrm{C} 1, \mathrm{C} 3, \mathrm{C} 4, \mathrm{C} 5, \mathrm{C} 6, \mathrm{C} 11 \\
\mathrm{C} 12, \mathrm{C} 15\end{array}$ \\
\hline & Substitution/reduction of materials & \\
\hline & $\begin{array}{l}\text { - } \quad \text { Packing reduction, substitution of packing materials and } \\
\text { use of recyclable packages and bottles } \\
\text { - } \quad \text { Reuse of containers and pots }\end{array}$ & $\begin{array}{l}\mathrm{C} 1, \mathrm{C} 2, \mathrm{C} 3, \mathrm{C} 4, \mathrm{C} 5, \mathrm{C} 8, \mathrm{C} 9 \\
\mathrm{C} 10, \mathrm{C} 11, \mathrm{C} 12 \\
\mathrm{C} 4, \mathrm{C} 5, \mathrm{C} 7, \mathrm{C} 8, \mathrm{C} 11, \\
\mathrm{C} 15, \mathrm{C} 16 \\
\mathrm{C} 2, \mathrm{C} 4\end{array}$ \\
\hline \multirow[t]{4}{*}{ Processes } & $\begin{array}{l}\text { - Redesign of production processes to save water or to } \\
\text { reduce pollution }\end{array}$ & $\mathrm{C} 1, \mathrm{C} 6$ \\
\hline & - $\quad$ Adoption of more environmentally friendly technologies & $\mathrm{C} 3, \mathrm{C} 7, \mathrm{C} 14$ \\
\hline & $\begin{array}{l}\text { - Byproducts and waste are processed or sold to } \\
\text { manufacture additional products }\end{array}$ & C9 \\
\hline & - $\quad$ Substitution of fuels in service delivery processes & C14 \\
\hline
\end{tabular}




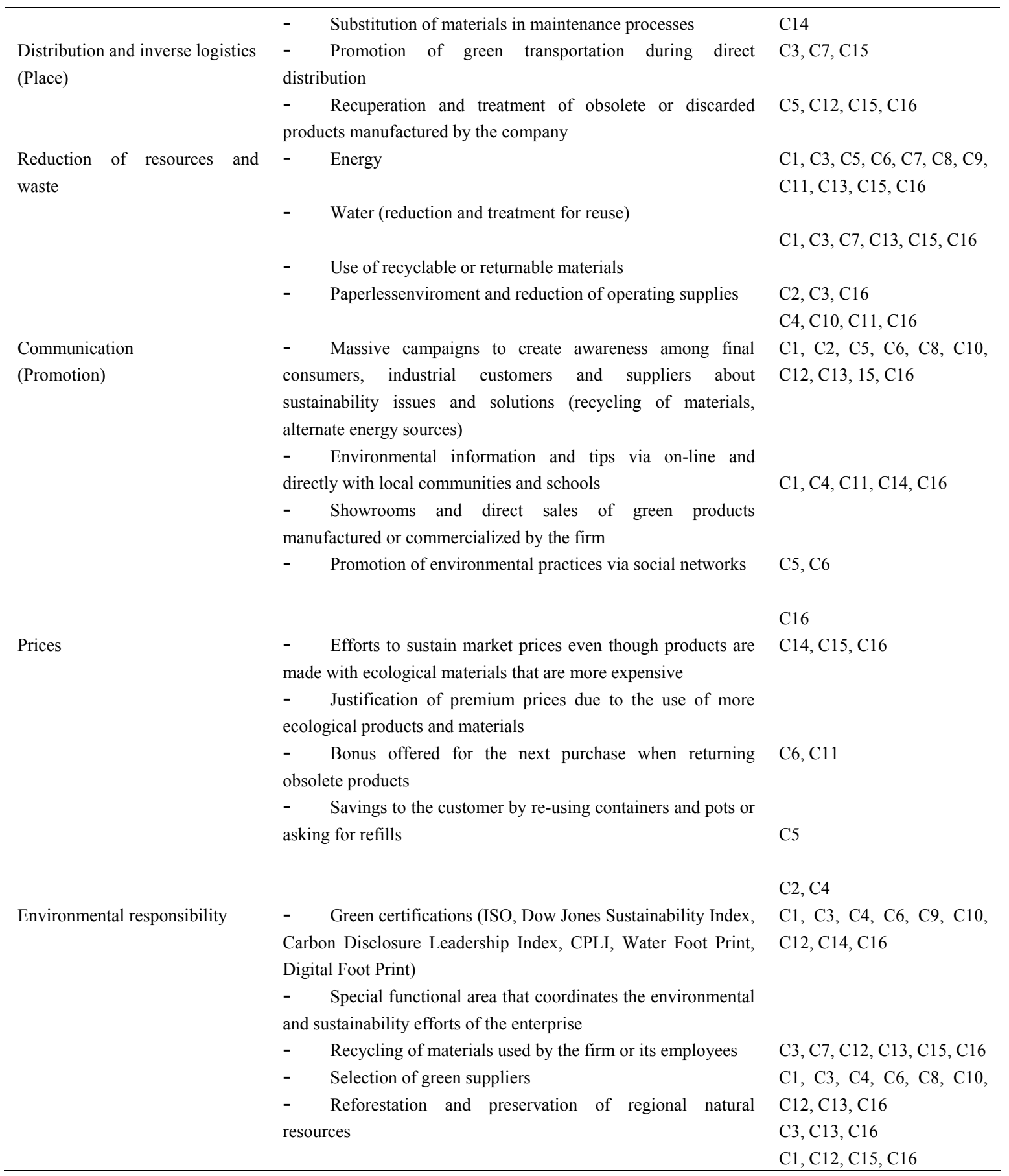

Within the general classification of green strategies provided by Cronin et al. (2011), we identified two main greening strategies.

a) Resource savings and waste reduction. As expected, the most popular environmental actions declared by the interviewed firms correspond to a general greening strategy related to energy and water savings, with process efficiency in second place. Through these actions, the firms both promote a "green" image in the market and attain benefits in terms of cost cuts and the control of air emissions, pollution and disposal of industrial sewage. The high cost of energy and fuels (gas and petrol) in Mexico stimulates firms to save or use alternative sources of energy as demonstrated in the following quotations:

In $2002 \ldots 49$ solar collectors were install to warm water... thermal sleeves were mounted in injection machines to reduce the use of electric energy... In 2006 we increase the number of containers for the treatment of residual water and in 2007 grease traps ... to filter water and reuse it for irrigation. In 2008 we changed lamps to save 
energy (C3, multinational).

The implementation of a Reverse Osmosis System improves the quality of water to generate vapor and reduces water and air emissions... the reduction in the [number] of blow purges also reduces fuel consumption (C1, multinational).

We acquired technology to treat sewage... we conducted studies about water pollution and have indexes related to how the areas nearby the processing plant are affected... the mud produced after treating the water may be used as fertilizer... there are also bacterial treatments (B6, Mexican with foreign operations).

In addition, around half of the multinationals and Mexican firms with foreign operations have introduced new process technologies to improve their process efficiency and save energy:

...adoption of a [alternate technology] with the lowest worldwide fuel consumption and with $18 \%$ less carbon-dioxide emissions than other technologies (C14, multinational).

Mexican local firms do not report any efforts to green their processes.

Other frequent resource savings are related to the use of recycled materials and the reduction of operating supplies in low value added operations. These types of savings were more commonly reported by small Mexican local firms:

We substitute presentation cards, sheets, flyers for recycled materials. Even the employees uniforms are made with PET recycled fibers... (A11, Mexican local).

We try to reduce printing and all the sheets are recycled (A10, Mexican local).

Meanwhile, three of the largest companies (one multinational and two Mexican with foreign operations) sell their byproducts to the manufacturers to reduce solid waste:

All the solid waste [of our main production lines] and discarded packages are sold to enterprises that use them as inputs for multiple products (C9, multinational).

b) Certification and acknowledgment of environmental responsibility. The second general greening strategy identified by Cronin et al. (2011), implementation of a formal environmental management system, was observed by several firms. But in general, the social pressure of environmentalist groups and the Mexican government efforts to regulate environmental issues have resulted in the consideration of the environmental sustainability concept into the firm's business practices.

In the case of multinationals, the majority of them have green certifications (11 out of the 16 surveyed) and have created special functional areas responsible of the administration of their environmental programs (6 out of the 16 multinationals). The following quotations exemplify this point:

...our investors are progressively giving more importance to sustainability issues. The actions of the enterprise are included in many indexes and sustainability funds. For example, since 1999 the enterprise has been continuously represented in the Dow Jones Sustainability Index and in the Carbon Disclosure Leadership Index since 2011 (C1, multinational).

There is a team dedicated to the sustainability topic. This [staff] is working in the understanding of the best technologies we may adopt in terms of cost and benefit [to the environment] (C7, multinational).

In contrast, most of the Mexican companies have not formalized or certified their environmental actions. Only three of the seven Mexican firms with foreign operations have green certifications. A similar situation is observed in the group of local Mexican firms, where only 3 out of 11 are green certified.

As recognized by Miles \& Russell (1997) and Cronin et al. (2011), the value of this green certification strategy in the market is unclear because many of the actions to get official recognition are internal (Note 1).

Evidence of the implementation of the last greening strategy, management of the supply chain, was not found after the analysis. None of the interviewed firms declared making special efforts with a transformational leadership to collaborate with their business partners to green the chain, or to integrate the forward and reverse flows of products to minimize the impact of their business activities on the environment (Defee et al., 2009).

With respect to the second general environmental strategy, green innovation, none of the interviewed firms was identified as a leader in green innovations. In the case of small Mexican companies with only local operations, some have an exclusive offer of ecological products but they are not manufactured by the company that only acts as a distributor. These enterprises are the result of eco-entrepreneurship efforts and since their creation, they decide to serve the green market by offering a variety of environmental friendly products (solar panels, 
bio-plastics, re-manufactured and recycled products). With respect to larger companies, especially the multinationals, several of them have extended their product lines by developing green products. However, these ecological innovations are only a sub-group of their product innovations; for this reason these product extensions are discussed in the following section. Finally, any indication of a green alliance strategy was not observed at all in this study.

\subsection{Green Marketing Strategies}

This section outlines the marketing strategy followed by firms operating in Mexico to address the second objective of the study. To accomplish this, environmental actions described in Tables 2, 3 and 4 were additionally organized after the four marketing Ps: product (re-design), communication (promotion), distribution (place), and price strategies.

Table 5. Examples of specific actions among 4Ps of green marketing

Products

- $\quad$ Substitution/reduction of materials

- Packing reduction, substitution of packing materials and use of recyclable packages and bottles

Promotion

(Communication)
Research and development, an manufacturing of green products (radical and incremental innovations)
- $\quad$ Reuse of containers and pots

- Massive campaigns to create awareness among customers and suppliers about sustainability issues and solutions (recycling of materials, alternate energy sources)

\footnotetext{
- Environmental information and tips via on-line and directly with local communities and schools
}

- $\quad$ Showrooms and direct sales of green products manufactured or commercialized
[We] created prototypes with zero-emissions [including] electric vehicles and hybrids... [these vehicles] are tendered to institutions and customers to get feedback... to improve them. We expect in 2013 to have an electric car with zero emissions... The car was designed based on customer needs... the vehicle facilitates mobility in megacities... with high traffic and represents [benefits] to the environment and to the economy of the buyers (C6, multinational).

[We have multiple products] the biodegradable pen, synthetic grass with a wheat base... we even have [biodegradable] jewelry... this kind of product is uncommon in Mexico, we are the first [local] firm truly specialized... and we sell at retail but also in large quantities to distributors... (A8, Mexican local).

[Within one of our product lines] we have redesigned packages with FSC [Forest Stewardship Council] certification. They use $40 \%$ recycled paper... PET pots have $50 \%$ of recycled materials. The refills are made from green plastic instead of petroleum. This green plastic is $100 \%$ recyclable and reduces $97 \%$ the generation of residuals ( $\mathrm{C} 4$, multinational).

The firm reuses containers for the products, and also we have a campaign that encourages the consumer to reuse bags and glasses ( $\mathrm{C} 2$, multinational).

In collaboration with Wal-Mart we are making an advertising campaign to encourage the use of biodegradable products. With [other] private companies we are promoting the use of green products. [We also] have joint campaigns with the government to stimulate the use of biodegradable products (A10, Mexican local).

Through the Web page we have on-line campaigns and annual reports about sustainability topics which are directly sent to several stakeholders... [we also have] campaigns through social networks as well as conferences and talks at schools (B3, Mexican foreign).

We directly commercialize products and services that create awareness about the positive use of alternate sources of energy (B1, Mexican international).

Our major coverage method [to approach consumers 
by the firm

- $\quad$ Promotion of environmental practices via social networks

Prices

- $\quad$ Bonus offered for the next purchase when returning obsolete products

- Savings to the customer by reusing containers and pots or asking for refills

- Justification of premium prices due to the use of more ecological products and materials about sustainability issues] is the social networks, including Face book, Twitter, and YouTube... (A3, Mexican local).

We try to have accessible prices by reducing the cost of fleets and other [logistics] costs... we also try to reduce the cost of materials, increase marginal efficiency ... and decrease the amount of materials [to reduce global costs] (A7, Mexican local).

Since green products require more... work, they usually have high prices with respect to regular products, but... consumers who buy these products have higher purchasing power. The products are promoted as friendly with the environment, but their additional benefits are also mentioned in order to show potential buyers that besides the positive environmental impact they have higher quality (C11, multinational).

[There is a green campaign] focused to environmental preservation that consistsof the recuperation of obsolete electronics, [a third party] recycles these products and the consumer receives a bonus or discount to buy a new product. The bonus [value] depends on the conditions, year, and model [of the returned product] (C5, multinational)

... the refill options for our products not only reduce the environmental impact but represent savings of $20 \%$ to the customer ( $\mathrm{C} 4$, multinational).

Relevant quotations are reported in Table 5. Distribution (place) is not included in the table because only a few of the companies (almost exclusively multinationals) reported actions related to green transportation (use of carbon trading schemes, full-truck transportation and substitution/maintenance of vehicles) or the adoption of the green supply chain concept. The following quotation is representative of this type of distribution efforts:

"We have worked with our suppliers to have the friendliest environmental transportation (C3, multinational)".

In terms of product strategies, multinationals and large Mexican companies with foreign operations are the most innovative in product design. Redesign of the product goes from reduction in the use of raw materials or package (most companies) to investment in $\mathrm{R} \& \mathrm{D}$ to develop products that consume fewer resources (water or energy). However, as previously stated, none of the companies are completely engaged with ecological innovations.

With respect to price, the two main strategies are: 1) prices similar to those of regular products as a result of cost cuts in other activities such as logistics and promotion and 2) justification of premium prices because the product has green attributes that are more expensive. The first strategy is deployed mainly by small local companies that try to gain market share while the second strategy was more frequently cited by multinationals and large Mexican companies that are aware that green consumers are less sensitive to price.

Finally, communication activities include massive campaigns, direct communication especially in schools and use of social networks to inform and persuade individuals to adopt pro-environmental behaviors. Large companies sponsor these types of efforts and also use massive media to communicate their own green marketing activities. On the other side, small companies have created alliances with large retailers and government agencies to implement communications campaigns focused on promoting reduction of consumption, reutilization and recycling of products among the population. 


\section{Conclusions}

\subsection{Academic Contribution}

The categorization of green actions as elements of the four marketing Ps may be useful to assess the progress of a firm's marketing strategy and identify opportunities for improvement. The exclusive diffusion of the firm's green actions, which has been a general practice among firms, is at most social advertising and may contribute to the consumer's confusion and loss of confidence (Melton \& Tinsley, 1999). The potential of the green marketing concept has not yet realized by firms operating in Mexico. This is evidenced by the two main strategies observed: "resource savings and waste reduction", and "certification and acknowledgment of environmental responsibility". This work aims neither to evaluate the effectiveness of these green strategies nor to catalogue them as "false green marketing". It instead seeks to highlight that present greening strategies reflect a short-term perspective and represent a relative low functional complexity for implementation. These strategies are focused not on long-term eco-efficiency and sustainability resulting from integrating economic, social and environmental issues into organizational performance, but on: a) immediate benefits related to cost, productivity improvement and avoidance of legal penalties and social conflicts (Banerjee, 2002); and b) medium-term advantages associated with an environmental responsibility oriented to gain legitimacy and the right to self-regulate and certify their ecological initiatives (Carrete, Arroyo and Trujillo, 2014a). The lack of a long-term perspective, top management commitment and low environmental governmental and public demands (Banerjee, 2002; Cater, Prasnikar and Cater, 2009) for environmental problems results in limited product or process innovation and little interest in building closed-loop supply chains to minimize the environmental impact of manufactured products along their life cycles.

The study results reveal the absence of an authentic green marketing strategy that integrates all the elements of the marketing mix to improve environmental performance and in the long run to advance the competitive position of the firm. For example, the concepts of green supply, green transportation and reverse logistics that are part of the distribution component are ignored by most of the enterprises. The green practices implemented by most of the interviewed firms (mainly Mexican) correspond to: 1) a tactical or passive marketing strategy which not involves the whole organization and is defined at the middle management level (Rivera-Camino, 2007); or 2) a lean or defensive green marketing strategy with a narrow functional range, partial coverage of the elements marketing mix and unsupported by all functional areas (Chen \& Lin, 2011). But when an organization does not have adequate green capabilities, serves a market uninterested in ecological products or services and operates under weak environmental public and legal pressure, it is more appropriate to follow a tactical or operative strategy that allows the introduction of environmental actions in an incremental manner (Fraj et al., 2011). This is the case of the Mexican context, where consumers are not particularly enthusiastic to perform pro-environmental behaviors (Carrete, Arroyo \& Trujillo, 2014b) and environmental regulations are more oriented to pollution control than to environment protection and restoration (InstitutoNacional de Ecología [INE], 2014). This setting does not stimulate firms to integrate their green practices into their marketing strategy and offers and explanation to the observed marketing strategies.

The enterprises with more proactive green marketing strategies are larger ones. Multinationals in particular, have more advanced marketing strategies (quasi-strategic or strategic according to Rivera-Camino, 2007) than Mexican firms, especially the local ones. This situation was also observed by Carter et al. (2009) in the case of Slovenian manufacturing companies which operate in a similar developing context like Mexico. The most outstanding differences between large and small firms were observed in distribution and product innovation. With respect to the product component, multinationals cited more frequently they are conducting research to develop ecological products that complement or enhance their current regular lines. Product R\&D was also part of the strategy of large Mexican firms with foreign operations while for 5 of the 11 local Mexican enterprises, the product component was exclusively addressed via the commercialization of green products. The greater product innovation efforts reported by firms with international operations may be attributed to the growth of the global green market. The need to fulfill international environmental regulations also seems to contribute to the superior interest of transnationals to go beyond compliance with legislation and include green practices as part of their CSR policies. This last statement goes in line with the results reported by Fraj et al., (2011) for Spanish firms and Carrete et al. (2014a) for Mexican firms.

A company can be said to have a pro-active green marketing strategy only if it systematically plans to integrate environmental activities into its long-term general strategy. Besides defining what are the current green marketing strategies pursued by firms operating in Mexico, future research requires to find out what strategies enhance business and environmental performance, which factors influence the implementation of an authentic green strategy and how this elements are related (Carrete et al., 2014a). The results of this study only show 
current green marketing practices but the elaboration and validation of a causal model as suggested by Cater et al. (2009) is going to be addressed to complete this research and enhance the body of knowledge in the area of green marketing.

This study is not without limitations. Even though multiple cases covering enterprises with different profiles were included, the results cannot be generalized to the total population of enterprises that operate in Mexico.

\subsection{Practical Implications}

The experience of the cases analyzed indicates firms operating in Mexico argue the actual low environmental consciousness of the market does not favor the deployment of a green marketing strategy. However, the concern about the environment is increasing and eventually public and legislative pressure will drive firms to integrate an authentic green marketing strategy. Those enterprises that decide to compete in their markets by being green will find relevant the following recommendations:

1) Define product, price, communication (promotion) and distribution (place) based on comprehensive market research to match the ecological attributes with the consumer needs, attitudes, knowledge and values;

2) Take a long-term approach to environmental problems that goes beyond adaptations or low-value modifications of products and processes, i.e. avoid "green harvesting";

3) Analyze the impact of product and processes along the complete product life cycle and consider that true green marketing efforts need to go beyond design and production;

4) Include in the communication component both the current environmental actions of the firm and information that helps consumers to change their lifestyles;

5) Design good metrics to measure the benefits of environmental efforts and the advantages of a positive "green image" that can't be measured in cost terms; and

6) Remember that CRS is a shared responsibility. Marketing can offer valuable ideas to go beyond compliance with current regulations.

Mexican environmental regulations may be designed to motivate firms to engage in more transcendental environmental practices, in particular for local Mexican firms. At the beginning of the 1990s with the General Law of Ecological Equilibrium and Environment Protection, regulations for the protection, conservation and rational use resources were formally considered by the Mexican government (INE, 2013). Increased surveillance and fines were imposed on organizations and as a result, large corporations implemented anti-pollution measures but smaller firms expressed great concern for the associated costs. Given these antecedents, policy makers would need to take into account 1) the costs borne by firms, 2) offer some kind of incentives (e.g. tax reduction), 3) give financial support for the acquisition of cleaner technologies and 4) provide evidence of the long-term savings associated with efficient and non-pollutant processes.

\section{References}

Banerjee, S. B. (2002). Organizational strategies for sustainable development: developing a research agenda for the new millennium. Australian Journal of Management, 27, 105-115. http://dx.doi.org/10.1177/031289620202701S11

Barkin, D. (2004). La responsabilización ambiental de las empresas en México. Comercio Exterior, 54(10), 1040-1055.

Baumann, H., Boons, F., \& Bragd, A. (2002). Mapping the green product development field: engineering, policy and business perspectives. Journal of Cleaner Production, 10, 409-425. http://dx.doi.org/10.1016/S0959-6526(02)00015-X

Bhat, V. (1993). Green marketing begins with green design. The Journal of Business \& Industrial Marketing, 8(4), 26-31. http://dx.doi.org/10.1108/08858629310047243

Boyatzis, R. E. (1998). Thematic Analysis and Code Development. Transforming Qualitative Information. Sage Inc.

Carrete, L., Arroyo, P. E., \& Trujillo, A. (2014a). Why do firms implement voluntary environmental actions and how are these activities evaluated? An empirical investigation in Mexico. Journal of Strategic Marketing. Under review.

Carrete, L., Arroyo, P. E., \& Trujillo, A. (2014b). Uso de la Teoría de la Conducta Planeada para explicar cuatro conductas ambientales [Theory to of plannedbehavior to explainfour pro-environmentalbehaviors]. 
Psyecology. Under review.

Cater, T. Z., Prasnikar, J., \& Cater, B. (2009). Environmental strategies and their motives and results in Slovenian business practice. Economic and Business Review for Central and South-Eastern Europe, 11(1), $55-73$.

Chan, R. (1999). Environmental attitudes and behavior of consumers in China: Survey findings and implications. Journal of International Consumer Marketing, 11(4), 25-54. http://dx.doi.org/10.1300/J046v11n04_03

Chan, R., \& Lau, L. (2000). Antecedents of green purchases: a survey in China. Journal of Consumer Marketing, 17(4), 338-357. http://dx.doi.org/10.1108/07363760010335358

Chen, C. S., \& Lin, L. Y. (2011). A new framework: make green marketing strategy go with competitive strategy. Journal of Global Business Management, 7(2), 1-6.

Commission of the European Communities. (2001). Green Paper-Promoting a European framework for Corporate Social Responsibility. $\quad$ Retrieved from http://eur-lex.europa.eu/LexUriServ/site/en/com/2001/com2001_0366en01.pdf

Cronin, J. Jr., Smith, J. S., Gleim, M. R., Ramírez, E., \& Martínez, J. D. (2011). Green marketing strategies: an examination of stakeholders and the opportunities they present. Journal of the Academy of Marketing Science, 39, 158-174. http://0-dx.doi.org.millenium.itesm.mx/10.1007/s11747-010-0227-0

Dangelico, R. M., \& Pujari, D. (2010). Mainstreaming green product innovation: why and how companies integrate environmental sustainability. Journal of Business Ethics, 95, 471-486. http://0-dx.doi.org.millenium.itesm.mx/10.1007/s10551-010-0434-0

Defee, C., Esper, T., \& Mollenkopf, D. (2009). Leveraging closed-loop orientation and Leadership for environmental sustainability. Supply Chain Management: AnInternational Journal, 14(2), 87-98. http://0-dx.doi.org.millenium.itesm.mx/10.1108/13598540910941957

Esty, D., \& Winston, A. (2009). Green to gold. How smart companies use environmental strategy to innovate, create value, and build competitive advantage. Hoboken, N. J.: Wiley\& Sons Inc.

Fotopoulos, C., \& Krystallis, A. (2002). Purchasing motives and profile of the Greek organic consumer: A $\begin{array}{lllll}\text { countrywide survey. British Food Journal, } & \text { 104(8/9), }\end{array}$ http://dx.doi.org/10.1108/00070700210443110

Fraj, A. E., Martínez, S. E., \& Matute, V. J. (2011). Marketing y medio ambiente: Una aproximación a la situación de la industria española. Universia Business Review, 156-183.

Fraj, A. E., Martínez, S. E., \& Matute, V. J. (2008). A multidimensional approach to the influence of environmental marketing and orientation on the firm's organizational performance. Journal of Business Ethics, 88, 263-286. http://0-dx.doi.org.millenium.itesm.mx/10.1007/s10551-008-9962-2

Gobbi, Ch. (2011). Designing the reverse supply chain: the impact of the product residual value. International Journal of Physical Distribution \& Logistics Management, 41(8), $768-796$. http://0-dx.doi.org.millenium.itesm.mx/10.1108/09600031111166429

Guide, V. Jr., \& Van Wassenhove, L. N. (2009). The evolution of closed-loop supply chain research. Operations Research, 57(1), 10-18. http://dx.doi.org/10.1287/opre.1080.0628

Hemphill, T. A. (1995). Enterprise strategy and corporate environmental alliance. Business Forum, 21(2), 8-12.

Instituto Nacional de Ecología [NationalInstitute of Ecology]. (2013). Regulación ambiental. Retrieved from http://www2.inecc.gob.mx/publicaciones/libros/47/cap2.html

Jamali, D. (2008). A stakeholder approach to corporate social responsibility: a freshperspective into theory and $\begin{array}{lllll}\text { practice. Journal } & \text { Business }\end{array}$ http://0-dx.doi.org.millenium.itesm.mx/10.1007/s10551-007-9572-4

King, S. (1985). Has marketing failed, or was it never really tried? Journal of Marketing Management, 1, 1-19. http://dx.doi.org/10.1080/0267257X.1985.9963971

Kotler, P., \& Levy, S. (1969). Broadening the concept of marketing. Journal of Marketing, 33(January), 10-15. http://dx.doi.org/10.2307/1248740

Leonidou, C. N., \& Leonidou, L. C. (2011). Research into environmental marketing/management: a bibliographic analysis. European Journal of Marketing, 45(1/2), 68-103. http://0-dx.doi.org.millenium.itesm.mx/10.1108/03090561111095603 
Lyon, T., \& Maxwell, J. (1999). Corporate environmental strategies as tool to influence regulation. Business Strategy and the Environment, 8, 189-196. http://dx.doi.org/10.1002/(SICI)1099-0836(199905/06)8:3<189::AID-BSE194>3.0.CO;2-0

Manaktola, K., \& Jauhari, V. (2007). Exploring consumer attitude and behaviour towards green practices in the lodging industry in India. International Journal of Contemporary Hospitality Management, 19(5), 364-377. http://0-dx.doi.org.millenium.itesm.mx/10.1108/09596110710757534

McDaniel, S., \& Rylander, D. (1993). Strategic green marketing. Journal of Consumer Marketing, 10(3), 4-10. http://dx.doi.org/10.1108/07363769310041929

Melton, K. M., \& Tinsley, S. (1999). Outlook for greener marketing: unsettled and cyclonic. Eco-Management and Auditing, 6, 86-97. http://dx.doi.org/10.1002/(SICI)1099-0925(199906)6:2<86::AID-EMA101>3.0.CO;2-L

Menguc, B. \&Ozanne, L. (2005). Challenges of the green imperative: a natural resource based approach of the environmental orientation-business performance relationship. Journal of Business Research, 48, 430-438. http://dx.doi.org/10.1016/j.jbusres.2003.09.002

Miles, M., \& Russell, G. (1997). ISO 14000 Total Quality Environmental Management: the integration of Environmental Marketing, Total Quality Management, and Corporate Environmental Policy. Journal of Quality Management, 2(1), 151-168. http://dx.doi.org/10.1016/S1084-8568(97)90026-2

Milliman, J., Ferguson J., \& Sylvester, K. (2008). Implementation of Michael Porter's strategic corporate social responsibility model. The Journal of Global Business Issues, 2(2), 29-33.

Moir, L. (2001). What do we mean by corporate social responsibility? Corporate Governance, 1(2), 16-22. http://dx.doi.org/10.1108/EUM0000000005486

Ottman, J. A., Stafford, E. R., \& Hartman, C. L. (2006). Green marketing myopia. Environment, 48(5), 22-36. http://dx.doi.org/10.3200/ENVT.48.5.22-36

Peattie, K., \& Crane, A. (2005). Green marketing: legend, myth, farce or prophesy? Qualitative Market Research, 8(4), 357-370. http://dx.doi.org/10.1108/13522750510619733

Porter, M., \& Kramer, M. (2006). Strategy and society: the link between competitiveadvantage and corporate social responsibility. Harvard Business Review, 78-93.

Rao, K. N., \& Reddy, G. V. (2012). Green entrepreneurship- A paradigm shift towards environment consciousness. Asia Pacific Journal of Management \& Entrepreneurship Research, 1(3), 112-118.

Rivera-Camino, J. (2007). Re-evaluating green marketing strategy: a stakeholder perspective. European Journal of Marketing, 41(11/12), 1328-1358. http://0-dx.doi.org.millenium.itesm.mx/10.1108/03090560710821206

Rondinelli, D., \& Berry M. (2000). Multimodal Transportation, Logistics, and the Environment: Managing Interactions in a Global Economy. European Management Journal, 18(4), 398-410. http://dx.doi.org/10.1016/S0263-2373(00)00029-3

Roper, A. S. W. (2003). Green Gauge Report 2002 Americans Perspective on Environmental Issues Yes...But. Retrieved from http://courses.be.washington.edu/LARCH/361/extra\%20readings/relations\%20to\%20nature/Green\%20Gua ge\%20Report\%20-\%20Americans\%27\%20Perspectives\%20on\%20Env\%27tal\%20Issues.pdf

Srivastava, S. K. (2007). Green supply-chain management: A state-of-the-art literature review. International Journal of Management Reviews, 9(1), 53-80. http://dx.doi.org/10.1111/j.1468-2370.2007.00202.x

Yi-Chan, C., \& Tsai, C. (2007). The effect of green design activities on new product strategies and performance: An empirical study among high-tech companies. International Journal of Management, 24(2), 76-288.

Yin, H., \& Ma, C. (2009). International integration: a hope for a greener China?.International Marketing Review, 26(3), 348-367. http://dx.doi.org/10.1108/02651330910960825

Yin, R. K. (2003). Case Study Research: Design and Methods. Thousand Oaks: Sage Inc.

Zhou, S. (2009). External Motivating Factors for Greening Small-and Medium-sized Enterprises in China. IIIEE Master Thesis. MESPOM Programme in Environmental Sciences, Policy \& Management. Lund, Sweden. Retrieved from http://lup.lub.lu.se/luur/download?func=downloadFile\&recordOId=1513628\&fileOId=1513629 


\section{Note}

Note 1. The Mexican Center for Philanthropy (CEMEFI) is the recognized institution that grants Social Responsibility certifications (ESR distinction). This civil association has established standards for this certification that include the preservation of the environment.

\section{Copyrights}

Copyright for this article is retained by the author(s), with first publication rights granted to the journal.

This is an open-access article distributed under the terms and conditions of the Creative Commons Attribution license (http://creativecommons.org/licenses/by/3.0/). 